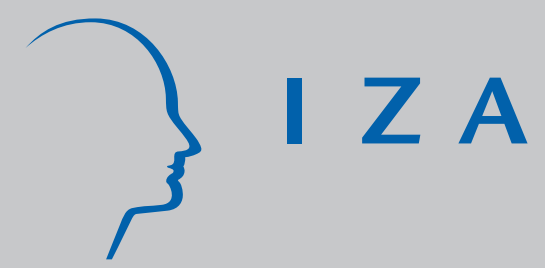

IZA DP No. 10110

The Long-Term Impact of International Migration on Economic Decision-Making: Evidence from a Migration Lottery and Lab-in-the-Field Experiments

John Gibson

David McKenzie

Halahingano Rohorua

Steven Stillman

July 2016 


\title{
The Long-Term Impact of International Migration on Economic Decision-Making: Evidence from a Migration Lottery and Lab-in-the-Field Experiments
}

\author{
John Gibson \\ University of Waikato \\ David McKenzie \\ World Bank and IZA \\ Halahingano Rohorua \\ University of Waikato \\ Steven Stillman \\ Free University of Bozen-Bolzano and IZA \\ Discussion Paper No. 10110 \\ July 2016 \\ IZA \\ P.O. Box 7240 \\ 53072 Bonn \\ Germany \\ Phone: +49-228-3894-0 \\ Fax: +49-228-3894-180 \\ E-mail: iza@iza.org
}

\begin{abstract}
Any opinions expressed here are those of the author(s) and not those of IZA. Research published in this series may include views on policy, but the institute itself takes no institutional policy positions. The IZA research network is committed to the IZA Guiding Principles of Research Integrity.

The Institute for the Study of Labor (IZA) in Bonn is a local and virtual international research center and a place of communication between science, politics and business. IZA is an independent nonprofit organization supported by Deutsche Post Foundation. The center is associated with the University of Bonn and offers a stimulating research environment through its international network, workshops and conferences, data service, project support, research visits and doctoral program. IZA engages in (i) original and internationally competitive research in all fields of labor economics, (ii) development of policy concepts, and (iii) dissemination of research results and concepts to the interested public.
\end{abstract}

IZA Discussion Papers often represent preliminary work and are circulated to encourage discussion. Citation of such a paper should account for its provisional character. A revised version may be available directly from the author. 


\title{
ABSTRACT
}

\section{The Long-Term Impact of International Migration on Economic Decision-Making: Evidence from a Migration Lottery and Lab-in-the-Field Experiments*}

\begin{abstract}
We study how migration from a poor to a rich country affects key economic beliefs, preference parameters, and transnational household decision-making efficiency. Our setting is the migration of Tongans to New Zealand through a migration lottery program. In a tenyear follow-up survey of individuals applying for this program we elicit risk and time preferences and pro-market beliefs. We also link migrants and potential migrants to a partner household consisting of family members who would stay behind if they moved. We play labin-the-field games designed to measure the degree of intra-family trust and the efficiency of intra-family decision-making. Migration provides a large and permanent positive shock to income, a large change in economic institutions, and a reduction in interactions with partner household members. Despite these changes, we find no significant impacts of migration on risk and time preferences, pro-market beliefs, or in the decision-making efficiency of transnational households. This stability in the face of such a large and life-changing event lends credence to economic models of migration that treat these determinants of decisionmaking as time-invariant, and contrasts with recent evidence on preference changes after negative shocks.
\end{abstract}

JEL Classification: $\quad$ O12, F22, D13, D81, P1

Keywords: migration, economic beliefs, preferences, household efficiency, transnational household

Corresponding author:

John Gibson

Department of Economics

University of Waikato

Private Bag 3105

Hamilton 3240

New Zealand

E-mail: jkgibson@waikato.ac.nz

\footnotetext{
* The authors thank the Government of the Kingdom of Tonga for permission to conduct the survey there; the New Zealand Ministry of Business, Innovation and Employment for providing the sampling frame; Geua Boe-Gibson, Paul Merwood, Fred Rohorua, and the interviewers for assistance with the project; participants at various seminars for helpful comments, and most especially the study participants. Financial support from the World Bank Research Support Budget and Marsden Fund grant UOW1101 are gratefully acknowledged. Ethical approval for the study was received from the Human Ethics Committee of the Waikato Management School. The views expressed here are those of the authors along, and do not necessarily reflect the opinions of the World Bank, the New Zealand Ministry of Business, Innovation and Employment or the Government of Tonga.
} 


\section{Introduction}

Most economic models assume that discount rates, risk preferences and willingness to cooperate are "deep" parameters (or "primitives") in utility functions and hence are invariant to both past decisions and outcomes, and to policy (e.g. Lucas, 1976; Wolpin, 2013). Failure of these assumptions could result in inconsistent decision-making. For example, in the context of this paper, which focuses on the impacts of migration, the classic economic model has individuals compare the costs of migrating with the present discounted value of the income earned from migrating (Sjaastad, 1962). Later models emphasize risk, and household migration decisions (Stark and Bloom, 1985; Rosenzweig and Stark, 1989). Accordingly, households are assumed to take part in migration provided the discounted expected utility of migrating exceeds the costs of doing so, provided liquidity constraints don't bind. Yet if preferences are not stable, migration could potentially appear utility-maximizing before migration, but not utility-maximizing afterwards (or vice-versa), even if the earnings gains from migration turn out exactly as expected.

Empirical work has found evidence of history-dependent preferences in a number of settings. Starting in the 1990s, researchers have used lab experiments to test whether individual risk preferences depend on previous gains ("house money") and losses ("break even"). Both have been found to impact future risk preferences in different contexts (e.g. Thaler and Johnson 1990; Keasey and Moon 1996). More recent research has focused on the impact of negative shocks on risk preferences and time discounting. A number of studies have found that large unexpected negative shocks (e.g. natural disasters, stock market losses, experiences of violence) impact preferences, at least for some groups in the population (Eckel et al. 2009; Malmendier and Nagel 2011; Callen et al. 2014; Carvalho et al, 2016; Brown et al, 2016). These findings have led to development of theoretical models that incorporate history-dependence (Dillenberger and Rozen 2015).

However, a recent overview by Chuang and Schechter (2015) notes that even in the case of these extreme negative events, the literature has not delivered a consistent set of results regarding preference stability and many papers have struggled to obtain appropriate control groups. They also show that in the case of less extreme shocks like changes in income, unemployment, health status, and family composition many studies have found no changes in risk and time preferences. Jaeger et al. (2010) also found no impact of internal migration on risk preferences.

This paper considers the stability of economic beliefs, preferences, and transnational household efficiency in the context of the major positive change in life circumstances that comes from moving from a poor to 
a rich country. The context is the migration of Tongans to New Zealand through a migrant lottery program. This involves at least three major changes in life circumstances. The first is a massive, and permanent increase in income for those who migrate. In earlier work (McKenzie et al, 2010), we show this migration results in a 263 percent gain in income within the first year, while in recent work (Gibson et al, 2015), we show this income gain appears approximately stable over time, with migrants continuing to earn almost 300 percent more than non-migrants 10 years later, for an approximate life-time net present value income gain of US\$250,000. Second, this gain is accompanied by a major change in the institutions, values, and culture individuals are exposed to, with migrants experiencing a more individualistic and market-oriented economy. Third, it involves a prolonged separation between extended family members, with migrants moving with their spouse and children, but leaving their parents and siblings behind in Tonga. Such large, comprehensive, and permanent changes in life circumstances provide a stringent test of the malleability of economic preferences and beliefs.

We use a long-term follow-up survey of individuals who applied to the migration lottery ten years earlier, with comparison of the winners and losers in this lottery enabling us to obtain causal estimates of the migration impact. We measure risk aversion using both survey questions and incentivized experimental games, and time preferences through survey questions. We examine the extent to which individuals have changed their economic beliefs using the pro-market beliefs questions of di Tella et al. (2007). Each applicant is then linked to a partner household in Tonga that contains either their parent or sibling. Migrants are therefore in a different country from this partner, while the control group of non-migrants are typically living in the same village, and in some cases, even the same dwelling. Principal applicants and their partners then play three variants of an incentivized trust game in order to measure the efficiency of extended-household decision-making.

Despite the large changes in life circumstances that winning the migrant lottery entails, we find that international migration has no significant impact on any of our measures of preferences and beliefs. This includes a lack of significant effect on any of five different measures of risk preferences, any of three different measures of time preferences, any of four different measures of pro-market beliefs, and any of five different measures of household efficiency. We follow Young (2016) in conducting a randomizationinference based omnibus test of overall significance of all these outcomes and fail to reject the null that there is no treatment effect whatsoever $(p=0.738)$. We would reject such a test if there had been even relatively small average impacts of migration on preferences and beliefs. This stability in the face of such a large and life-changing event lends credence to economic models of migration that treat these 
determinants of decision-making as time-invariant and suggests that other large changes in circumstances that are voluntary in nature (e.g. marriage, childbearing, retirement) may also be unlikely to lead to changes in preferences and beliefs.

The remainder of the paper is structured as follows: Section 2 describes the context in which this migration flow is occurring, and describes the survey and estimation strategy; Section 3 reports on impacts on risk and time preferences; Section 4 covers the impact on pro-market beliefs; Section 5 reports on the impact on interactions with partners and on household efficiency; Section 6 discusses statistical power and external validity issues, and Section 7 concludes.

\section{Context and Survey}

\subsection{Country Context}

The Kingdom of Tonga is an archipelago of islands in the Pacific, with a resident population of just over 100,000 . It has a gross national income (GNI) per capita of \$5,069 (in 2011 PPP\$), slightly less than that of India, and ranks $132^{\text {nd }}$ out of 188 countries. ${ }^{1}$ Average income in New Zealand is approximately six times as high, at $\$ 32,689$. Both countries rank 32 places higher in the Human Development Index than they do in terms of per capita GNI.

Tonga has been and continues to be a less market-oriented economy than is the case in New Zealand. The Index of Economic Freedom ranks New Zealand third in the world, as a free, modern, and competitive economy, while Tonga is ranked as "mostly unfree" at $95^{\text {th }}$ in the world, between Swaziland and the Kyrgyz Republic (Heritage Foundation, 2016). Tongan society has historically been highly stratified, with a monarch and aristocracy controlling resources and a largely subsistence-oriented economy. The extended family plays an important role, with the kinship system expected to provide for everyone's financial needs and a strong culture of sharing and reciprocity (makafetoli'aki) (Ketu'u, 2014). However, over-time the economy has become more market-oriented than it was several decades ago, with individuals combining remittance income from abroad with income from farming and wage labor to purchase market goods and the Mormon church influence emphasizing a role for individual achievement (Addo and Besnier, 2008).

Emigration out of Tonga has been high, with more than 30,000 Tongan-born living abroad, mainly in New Zealand, Australia and the United States. Remittances from these migrants were equivalent to 28 percent of GDP in 2014 (World Bank, 2016), the fourth-highest in the world. Since the 1990s the main channels of

\footnotetext{
${ }^{1}$ All statistics in this section are from the 2015 Human Development Report (UNDP, 2015).
} 
emigration have tended to be through family reunification categories as destination countries imposed points-based systems for work migration that favored highly skilled migrants. In 2002, New Zealand introduced a new migration pathway, the Pacific Access Category (PAC). This allows a quota of 250 Tongans to permanently migrate each year. Any Tongan citizen aged 18 to 45 who meets certain English, health, and character requirements can register for this program and a lottery (random ballot) is used to select amongst the applicants. The odds of success were approximately eight percent during the 2002-05 years that our sample is drawn from. If their ballot is drawn, applicants have six months to find a full-time job offer in New Zealand, and then may immigrate with their spouse and any unmarried children aged under $24 .^{2}$ In contrast, any other family members, such as their parents and siblings, are ineligible to accompany them under the PAC rules and are difficult to subsequently sponsor under family reunification categories which primarily provide for marriage migration or which require an income or wealth threshold to be exceeded which excludes most Tongans.

\subsection{Survey}

Our initial work using this lottery was based on a survey that interviewed a subsample of applicants to the 2002-2005 ballots approximately one year after they had moved to New Zealand, which showed immediate large gains in income to the principal applicants who migrated (McKenzie et al, 2010). This sample including just over one-third of the migrants who moved to New Zealand, with many of the others reserved for a sample frame for an official government survey of different immigrant streams taking place at the same time. In late 2012 the research team received permission from the immigration authorities to view the names of all PAC ballot winners from the 2002 to 2005 ballots. There were a total of 4,696 applicants, of whom 367 were randomly selected as ballot winners. Official records based on passport scans showed that, by late 2012,307 of these winners (84\%) had approved residency applications and had ever migrated to New Zealand, while the remaining 60 winners did not migrate and are thus noncompliers to the treatment of migration.

Only the names and address details from seven to ten years earlier were available for these migrants. Using this information and an extensive, long, and expensive tracking procedure (described in more detail in Gibson et al, 2015) in both New Zealand and Tonga, between late 2013 and early 2015, we attempted to locate the ballot winners and interview them. Even less information was available for those who didn't migrate and so we used the home villages in Tonga of the migrants to sample the non-migrants and the

\footnotetext{
${ }^{2}$ See McKenzie et al. (2010) for more details of the PAC program.
} 
non-compliers. ${ }^{3}$ Our main survey approach was face-to-face interviewing using an extensive survey that asked about employment outcomes, took physical health measurements, asked about preferences, and played incentivized lab-in-the-field games which we describe in detail later in the paper. Each principal applicant in this long survey was linked to a partner, defined as either a parent or sibling, who, according to the PAC rules, would not be eligible to move to New Zealand even if the principal applicant was a ballot winner. These partners were used for the household efficiency game described in Section 5.

We supplemented this long, in-person, survey with a shorter telephone-based survey designed to reach those who had on-migrated from New Zealand or who were in less accessible parts of New Zealand. Since surveying often uncovers details for other people (through snowball effects) we also gave this short survey to some recently identified migrants in areas where the longer survey had already been fielded, as well as to additional households in Tonga.

Figure 1 details the sampling procedure by group. Altogether we have a sample of 282 principal applicants who received the long survey and played all the lab-in-the-field games, comprising of 133 migrants (out of 307 in total), 6 non-compliers (out of 60 in total), and 143 ballot losers (out of 4,329 in total). We have an additional 103 principal applicants who were given the short survey (61 migrants, 3 non-compliers, and 39 ballot losers) for a total sample of 385 principal applicants. In the end, we were able to survey 64 percent of the principal applicants who had ever migrated to New Zealand (Figure 1). Since noncompliers were sampled at a lower rate, we use the administrative data to reweight the migrants and non-complier samples to be representative of the ballot winners. We intentionally surveyed only enough ballot losers to optimize the power to detect impacts of migration and the vast majority of ballot losers we made contact with agreed to be interviewed.

Table 1 then provides some basic summary statistics for the ballot winners and ballot losers. Given the time that has passed since individuals applied for the ballot, we have few pre-determined characteristics on which to check balance: age, gender, and place of birth. We see that the principal applicants are 41 on average, two-thirds are male, and almost one-quarter were born in the outer islands. Although the ballot losers are slightly older, a joint test of orthogonality cannot reject the null hypothesis that age, gender, and birthplace are unrelated to treatment status $(p=0.306)$. This suggests that our treatment (ballot winner) and control (ballot loser) samples are comparable and we can use the random assignment

\footnotetext{
${ }^{3}$ Villages in Tonga average about 90 dwellings and so door-to-door methods are a feasible way to locate ballot losers and non-migrant winners.
} 
provided by the lottery to assess causal impacts. Nevertheless, we condition on age, gender, and island of birth to improve power and control for any effect of this slight difference in age.

The second half of Table 1 then shows characteristics that can change with migration. As shown in Gibson et al. (2015), winning the ballot results in substantially higher incomes for the principal applicants - an average of NZ\$410 per week for the ballot winners compared to NZ\$126 per week for the ballot losers. ${ }^{4}$ Many of the migrants also undertake some tertiary schooling after arrival in New Zealand, resulting in an additional year of education on average for the ballot winners. However, note that the ballot losers still average 12 years of schooling. As a result, education levels are high enough that there should not be a problem for participants to understand the experimental games (and indeed similar games have been used in populations with average schooling of half this level (Chuang and Schechter, 2015)). Both the ballot winners and losers have an average household size of around five persons, where household here refers to individuals living in the same dwelling. ${ }^{5}$ We see also from Table 1 that the average migrant has spent just over nine years in New Zealand.

\subsection{Estimation Strategy}

We estimate two parameters throughout. The first is the intention-to-treat (ITT) effect, of being offered the opportunity to migrate through the Pacific Access Category irrespective of whether the individual does migrate. We estimate the ITT through the following equation for a particular outcome for individual or household $i$ :

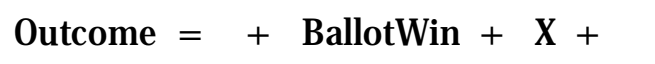

Where BallotWin takes value one if the principal applicant was chosen in the 2002 to 2005 Pacific Access Category ballots and zero otherwise, and $X$ is a vector of controls for the pre-determined characteristics (age, gender, and island of birth), for survey type (long or short), and for each of the different PAC ballot years that the individual entered. The median and modal applicant in our sample entered only one of the ballot years between 2002 and 2005. However, since those who entered multiple times had a higher

\footnotetext{
${ }^{4}$ Over the survey period the Pa'anga exchange rate averaged 0.65 NZD, and had a range of just three NZ cents. To allow comparison with results from other countries, the NZD-USD exchange rate averaged 1.33 over this period. The income gain is similar in PPP terms (see Gibson et al, 2015).

${ }^{5}$ This reflects both the establishment and growth of independent households in New Zealand among the ballot winners and a trend towards living in nuclear family in Tongan as households age. That fact that household size is the same suggests that migration does not impact decisions around childbearing and household organization.
} 
probability of getting chosen, we correct for this by conditioning on the lotteries entered (Abdulkadiroglu et al, 2011).

Second, we use assignment to the treatment (winning the PAC lottery) as an instrumental variable (IV) for the actual treatment of migrating, in regressions like:

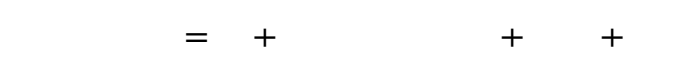

where Migrate $_{i}$ is a dummy variable that equals one if person $i$ ever migrated to New Zealand and is zero otherwise. The IV estimator of ${ }^{-}{ }^{-}$is a Local Average Treatment Effect (IV-LATE), interpreted in this case as the impact of migrating on people who would migrate only if they won the PAC lottery and not otherwise.

\section{Impact on Risk and Time Preferences}

There are several channels through which international migration might be hypothesized to affect risk and time preferences. The very act of moving to another country to set up a new life is a risky decision, and successfully doing this may lead to more confidence in taking subsequent risks (Krueger and Dickson, 1994). To the extent that cultures differ in risk attitudes or time preferences (Falk et al., 2016), moving to a new country entails exposure to this new culture. Migration also can affect education and wealth levels, and lifespans, which in turn may affect time preferences and risk attitudes.

\subsection{Existing Evidence of Migration Effects}

Risk is a key determinant of migration decisions and several studies have attempted to examine the association between risk preferences and migration, with an implied causal direction going from timeinvariant risk preferences to migration. Jaeger et al. (2010) use data from the German Socio-economic survey on an individual's self-reported propensity to take risks and find that individuals with higher risk propensities are more likely to migrate within Germany. ${ }^{6}$ Gibson and McKenzie (2011) use the same risk measure and find that amongst high-skilled people from three Pacific countries the more risk-seeking individuals are more likely to have emigrated. They also find that individuals who are more patient in a discounting question are more likely to have emigrated. Three recent papers have also examined the association between risk-seeking and internal migration within China. Akgüç et al, (2015) and Dustmann

\footnotetext{
${ }^{6}$ In addition to their main analysis which focuses on how risk preferences predict migration, they use panel data over two years to show that changes in migration status are not correlated with changes in self-reported risk attitudes over this short period.
} 
et al, (2015) use the same self-reported survey measure on propensity to take risks and find migrants are more risk-seeking, while Hao et al. (2014) use incentivized lotteries and find no difference in risk attitudes between migrants and stayers.

\subsection{Measurement}

We use two survey approaches and one incentivized lottery task to measure risk aversion. The first survey measure is the self-reported propensity to take risks used by Jaeger et al. (2010) and a number of other studies referenced above. This question asks individuals for their attitude toward risk in general, allowing respondents to indicate their willingness to take risks on an eleven-point scale, with 0 indicating complete unwillingness to take risks and 10 indicating complete willingness to take risks. The second survey measure is based on Barsky et al. (1997) and asks "Suppose you are the only income earner in your family, and you have a good job guaranteed to give you your current (family) income for life. You are given the opportunity to take a new job, with a 50:50 chance it will double your current income, and a 50:50 chance that it will cut your income by 20 percent. Would you take the new job?". Appendix 1 sets out the exact variable definitions used as outcomes.

Our incentivized lottery measure is based on Eckel and Grossman (2002) and is designed to be a simple way to elicit risk preferences through asking individuals to make only a single choice from a menu of options. Aside from only requiring one choice, another key advantage of this method reported by Charness et al. (2013) is that the measure is relatively easy for individuals to understand compared to more complicated lottery designs, and as a result can produce less noisy estimates of risk preferences when individuals have lower math abilities. Individuals choose between competing lotteries with payoffs that ranged from 0 to 40 pa'anga (US\$0 to US\$22). Each participant was paid according to his or her choices, with the expected value equivalent to approximately 2 to 4 hours of average earnings in Tonga. Based on these choices, we construct three variables to indicate whether they made an inefficient choice (that was dominated by other lotteries they could have chosen), a choice consistent with severe risk aversion, or a choice consistent with risk-seeking.

To account for multiple hypothesis testing in the risk domain and to examine an overall measure of risk attitudes, we construct an aggregate index which signs each risk measure so that a higher score indicates more risk-seeking and then takes the average of the standardized z-scores.

Time preferences were assessed using standard hypothetical questions which asked whether individuals would prefer an amount of money today compared to an amount one year from today, and also whether 
they would prefer an amount in one year versus two years. Individuals were coded as having a high discount rate if they would prefer NZ\$1000 today to NZ\$1500 one year from today, and as being a hyperbolic discounter if they had a higher discount rate when comparing today to one year than when comparing one year to two years. We also ask individuals the time period over which they make financial decisions, with individuals who think most about the next week coded as short-term planners. We then construct an aggregate index of the three measures in the time preference domain that we call the Aggregate Short-termism index, with higher scores indicating more short-term planning.

\subsection{Results}

Table 2 then reports the impact of winning the ballot (ITT) and impact of migrating to New Zealand (LATE) on these risk and time preferences. We see individuals appear more risk-seeking in the survey questions than in the incentivized game, with an average self-assessed propensity to take risks of 6.2 out of 10 and 52 percent saying they would take a riskier job with a chance of higher income, compared to just 6.3 percent choosing one of the two lottery options consistent with risk-seeking behavior. There is no significant impact of migration on any of these measures, nor on the aggregate index. One quarter of individuals say they would prefer $\$ 1500$ in one year to $\$ 1000$ today, 13 percent have a higher discount rate when comparing today with one year than one year with two years (consistent with hyperbolic discounting), and 75 percent say they have a short-term planning horizon of a year or less for financial decisions. We find no significant impact of migration on any of these measures, nor on the aggregate short-termism index.

Taken together, these results show that we cannot reject the hypothesis that risk and time preferences are stable in the presence of the major changes induced by international migration.

\section{Impact on Pro-Market Beliefs}

\subsection{Existing Evidence and Measurement}

There is limited existing evidence on how attitudes towards markets determine the migration decision or are in turn affected by migration. Williams et al. (2014) compare Nepali migrants living in the Gulf to nonmigrants in Nepal and find that migrants are more materialistic, although they are unable to determine causality. Osili and Paulson (2008a, b) document that immigrants to the United States from countries with more developed financial systems are more likely to own stock and use bank accounts, suggesting that home country institutional environment shapes trust and beliefs in the financial system. The question is 
then whether exposure to the more formal and market-oriented institutions of a developed country makes individuals more market-oriented in their beliefs?

Di Tella et al. (2007) provide evidence from a different setting to suggest that greater inclusion in a market economy can change beliefs. They argue that individualism, materialism, meritocratic inclinations and trust in others are necessary for the functioning of markets, and ask questions to measure these attitudes amongst squatters in Argentina, some of whom had been granted property rights. They find that those who were brought into the formal system through these property rights subsequently exhibited stronger pro-market beliefs. We use their same four questions to measure these different aspects of pro-market beliefs, and like them, to aggregate into an overall measure of pro-market beliefs (see appendix 1 ). As a small island nation, Tongans are much less reliant on impersonal markets for buying goods and making other transactions than are the majority of New Zealanders, hence one might expect that moving to New Zealand and using impersonal markets on a regular basis would lead to greater pro-market beliefs.

\subsection{Results}

Table 3 shows the impact of international migration on pro-market beliefs. Despite Tonga being classified as a mostly unfree economy (Heritage Foundation, 2016), we find market attitudes among the ballot losers to be substantially more pro-market than was the case of the land-squatters in di Tella et al. (2007). ${ }^{7}$ For example, 80 percent of the ballot losers believe you can succeed on your own, compared to only 33 percent of their control group, and 70 percent of our control group say you can trust others compared to only 34 percent of their control group..$^{8}$ Our sample still has room to be more pro-market, but is starting from a more market-oriented base than is the case of the sample of di Tella et al. (2007). We see from Table 3 that there is no statistically significant impact of international migration on any of these four measures, nor on the aggregate measure of pro-market beliefs. After almost a decade in New Zealand, we cannot reject the hypothesis that the Tongan migrants are more pro-market than similar individuals who never migrated.

\footnotetext{
${ }^{7}$ Since we do not have these measures for non-applicants, we cannot tell whether this reflects that individuals with pro-market attitudes are more likely to want to migrate, or whether Tongans in general have higher levels than the Argentine squatter sample of di Tella et al. (2007).

${ }^{8}$ We also have higher baseline means on the other two measures, which we code differently from them as a result (see appendix 1). Using their coding, $100 \%$ of our sample would give the materialistic answer compared to $50 \%$ of their control group; and $97 \%$ of our sample would say effort matters compared to $74 \%$ of their control group.
} 


\section{Impact on Interactions with Partners and Household Efficiency}

\subsection{Defining partners}

At the time of migration the principal applicants are typically adults in their late twenties or early thirties, who move with their spouse and children. When applying some would still have lived with their parents or siblings, or otherwise would typically have recently set up their own dwellings in the same small villages as their extended family members. A decade later, by the time of our follow-up survey at about age 40 , most would have formed their own households in Tonga if they had not been selected to migrate. We therefore defined for each principal applicant in the long survey a partner household in Tonga containing either a parent or elder sibling (with priority on parents over siblings, and females over males). A strict rule was used for matching so that the choice of partner household is orthogonal to winning the lottery. In about 15 percent of cases the partner was living in the same dwelling in Tonga as the ballot loser.

Each partner was then interviewed separately from the principal applicant. Table 4 provides some descriptive statistics on partners by treatment group. The partner is the parent of the principal applicant in 44 percent of the cases, and their sibling in the remainder. This is reasonably balanced by treatment status, although the ballot losers are slightly more likely to have a parent rather than sibling interviewed as the partner, but not significantly so. The partner age averages 66 for parents of the principal applicant and 52 for their siblings, for an average age of 54 . This is slightly higher for the ballot loser sample reflecting the higher incidence of parents. We see no significant difference by treatment status on other partner characteristics such as gender, education, or earnings. The latter result is consistent with Gibson et al. (2015) who find that the massive gains in income to the migrants are not accompanied by changes in the income of these partner households. We control for partner type (parent or not), partner gender, and partner age in our trust game regressions.

\subsection{Interactions with Partners}

Table 5 then examines how international migration has affected the different types of interactions principal applicants have with these partners. Column 1 shows that there is a large and significant reduction in regular communication. Over three-quarters (77\%) of ballot losers communicate at least weekly with their partner, while migrating lowers this by 35 percentage points. Column 2 shows there is a small positive, but insignificant, effect of migration on the likelihood the principal applicant sends money to the partner. This might seem surprising as we might expect migrants to be remitting, and non-migrants not to be. But this question does not capture the size of the transfer - migrants are likely to be making 
larger transfers. Moreover, inter-household transfers are common within Tonga, as seen by the control group mean proportion of 0.72 . In contrast to the lack of effect on transfers to the partner, in Column 3 we see a large reduction in receipt of money from the partner; 45 percent of ballot losers had received money at least several times a year from the partner, with these reverse flows of money not occurring for migrants.

Column 4 shows that migrants are more likely to say they would trust the partner to give something back to them if they loaned it, without having to ask multiple times. Column 5 and 6 look at knowledge about earnings of the other party. There is no significant impact on whether the principal applicant knows the partners earnings, but migration reduces the likelihood that the partner knows how much the principal applicant earns. Just over one-half (54\%) of ballot losers say they consult with the partner on financial decisions, while migration lowers this by 34 percentage points (Column 7). Partners also consult with the ballot losers on financial decisions just over half the time, with no significant impact of migration on this outcome. Migration lowers the likelihood of having a joint business with the partner (but not significantly), and increases the likelihood of owning livestock together. This latter effect could occur through partners looking after livestock for the migrant, which might be needed, for example, to donate to ceremonial feasts in the migrant's name.

Taken together these results suggest reductions in communication and knowledge flows, but also increases in some other types of interactions. We sign each variable so that a higher value indicates more interaction and construct an overall index of standardized z-scores. The last column shows that migration has an overall effect of reducing interactions, with the effect size equivalent to approximately one-third of a standard deviation.

\subsection{Measuring Household Efficiency Through a Trust Game}

The existing literature has noted that the separation of household members brought about by migration is likely to increase information frictions, and as a consequence, increase the likelihood of strategic behavior. As a result, the standard unitary model of the household seems unlikely to hold (Chen 2013, de Laat, 2014). In a lab-in-the-field experiment, Ambler (2015) finds that migrants strategically send less of a windfall as remittances when their choice is not revealed to recipients. Ashraf et al. (2015) find that migrants show demand for products that give more control over how the money they send back is saved. In contrast, de Arcangelis et al. (2015) find that information asymmetry does not determine how much migrants will remit for education purposes in their lab-in-the-field experiment. 
While these studies provide evidence against the unitary model of the household, none of them test whether migrant households are inefficient, nor whether migration has a causal effect on the efficiency of transnational household decisions. To investigate this question, we had principal applicants and their partners play three games (in random order) that are related to the widely used trust game of Berg et al. (1995). Appendix 1 provides the exact wording of these games. In the first two variants, the PAC principal applicant (who is either a migrant in New Zealand or an unsuccessful ballot holder or non-complier in Tonga) chooses how much to keep of a windfall of 300 pa'anga (US\$160) and how much to transfer to the other player, who is their parent or elder sibling in the partner household in Tonga. The player in the partner household then decides how much of the amount s/he has been sent to keep, and how much to put into a bonus pot.

The money in the bonus pot is multiplied by the value that comes up on a 4-sided dice and in the first variant goes to the PAC applicant (plus what they kept in the first stage), while in the second variant it goes to the player in the partner household (plus the amount they kept back from the bonus pot). In both these variants, the player in the partner household knows that the windfall was 300 pa'anga. In the third variant of the game, the windfall is either 100,300 or 500 pa'anga and the player in the partner household does not know the value of the windfall, just that it was somewhere between 100-500 pa'anga. The rest of this game proceeds as in the first variant, with the money in the bonus pot going to the first mover (either the migrant or unsuccessful PAC applicant). All three games were played by each principal applicant-partner pair, with the order of the games randomized. At the end of the three games, each player chose a number between 0 and 99, and if either number came up from the roll of two 10-sided dice, the payout from one of the games was made for real.

Because the players can then ex-post divide this money amongst themselves as they wish, in these games the efficient outcome for the extended household is for the first player to send the entire amount to the partner and for the partner to put the entire amount in the bonus pot where it will be multiplied by a number between 1 and 4 depending on the dice roll. However, if there is distrust over the likelihood that the other player in the game will put the money in the bonus pot, or will share any windfall at the end, players may keep some of the money. We then measure the efficiency of the transnational household by the share of the initial windfall that makes its way to the bonus pot.

Two approaches to implementing these games have been used in the literature. The game, or direct response, method has the first player play first and then the outcome of their actions is relayed to the second player who then makes their decision. In contrast, the strategy method asks respondents to reveal 
conditional decisions for every possible action - which in our case would require the partners to state how much they would put into the pot for all possible amounts they could receive. We use the direct response method given evidence in the literature that it can be easier for subjects to understand, and that behavior can differ under the strategy method (e.g. Casari and Cason, 2009; Brandts and Charness, 2011).

We believe these variants of the trust game have close parallels to the remittance decisions faced by migrants. Consider a migrant sending money home to an extended family member hoping that they will invest part of the money in an activity that will yield some return to the migrant in the long-run. The first version of the game mirrors this decision, with the migrant deciding how much to remit, the partner deciding how much of the remittance to keep for themselves versus devoting it to the investment activity, and then the migrant gaining the return from what is invested. The third version of the game would then correspond to this same decision when the partner does not know how much income or surplus income the migrant has to possibly invest in the first place. The second version of the game could correspond to the migrant deciding on remitting to the partner to have them make some longer-term investment, such as spending on education of nieces and nephews, with again the possibility that the money is instead kept by the partner and not invested.

\subsection{Results on Household Efficiency}

Figure 2 plots the extended household efficiency in version A of the game (when the principal applicant is the residual claimant of the bonus pot) against that in version $B$ (where the partner is the residual claimant). The first point to note is that most households are not acting efficiently. On average only about half of the windfall makes its way into the bonus pot. As a result, there is plenty of scope to potentially see differences in efficiency emerge with migration. However, the second point to note is that inefficiency seems prevalent for both ballot losers and ballot winners, with no strong difference apparent between the two. Third, we see that household behavior is strong correlated across the two games, with households that are more efficient under version $A$ also tending to be more efficient under version $B$. More of the points lies below the 45 degree line than above, which suggests efficiency is higher on average when the partner rather than the principal applicant is the residual claimant.

Figure 3 shows a similar pattern when comparing version C of the game (with partial information) to version A. Again there is a high correlation in behavior in the two games, ballot status does not seem strongly associated with game behavior, and there is more mass below the 45 degree line suggesting higher efficiency on average when only partial information is available. 
Table 6 then estimates the impact of international migration on extended household efficiency in these games. Column 1 shows that in game A, the ballot losers transfer on average only 47 percent of the windfall amount to the bonus pot, representing substantial inefficiency. Migration has no significant impact on the amount transferred, with the point estimate for the amount transferred to the bonus pot only 4 percentage points higher. Column 2 shows that household efficiency is approximately 4 percentage points higher in game $B$ than in game $A$, but that again there is no significant effect of migration on this efficiency. Column 3 shows that household efficiency is 2 percentage points higher in game $C$ than game A, but that again there is no significant effect of migration on this efficiency. The last two columns consider the difference between games $A$ and $B$, and between games $B$ and $C$, and finds that migration has no significant impact on either of these differences. Therefore, despite the reduction in interactions with the partner seen in Table 5, migrant households are no less efficient at decision-making.

Appendix 2 examines the impact of international migration on individual actions and beliefs within these trust games. We examine the share of the windfall kept by the principal applicant, the share of what the partner receives that the partner keeps, the principal applicant's beliefs about what the partner will do, and the degree of inaccuracy in these beliefs. For games A and B we see no significant impacts on any of these actions or beliefs. In game $\mathrm{C}$, with partial information, migrants keep a lower share of the initial windfall than non-migrants (significant at the 5 percent level), but there is no significant effect on any of the other actions or beliefs.

Although we do not find any significant impact of migration on household efficiency, it is still of interest to ask which characteristics of principal applicants and their partners are associated with more efficient outcomes. We pool together the migrant and non-migrant samples and examine this in Table 7. We focus on household efficiency in game $A$, because as we have seen behavior in the other games is strongly correlated with behavior in this game. We see in column 1 that household efficiency is higher the more years of education the principal applicant and their partner both have, suggesting that those with more skills are better able to achieve an efficient outcome in this game. We also find household efficiency is higher when the partner is a parent compared to a sibling. The remaining columns of the table then examine how household efficiency is correlated with the different types of interactions between principal applicants and partners. We see household efficiency is significantly higher when the principal applicants trust the partner more, when they already send money frequently to the partner, when the partner consults with them on financial decisions, and when they jointly own a business together. As a result, household efficiency is higher when our overall interactions index is higher. 
We therefore have the result that migration reduces interactions between principal applicants and their partners, and that fewer interactions are associated with lower household efficiency. The question that then arises is why we don't find a significant impact of migration on household efficiency. If we take the point estimates from Table 5, then the ITT of ballot winning is to lower the interactions index by 0.138 . Then from Table 7, a 0.14 reduction in the interactions is associated with a 0.018 reduction in household efficiency. This is a small effect and lies within the confidence interval seen in Table 6. Hence, although there are reasons to think migration would lower household efficiency, it seems the size of the effect is small in practice.

The lack of impact is also consistent with research on the strong persistence of some aspects of culture. Guiso, Sapienza, and Zingales (2006) show a strong correlation between the trust in others displayed by immigrants in the United States and the level of trust in their countries of origin, with this pattern still present even in subsequent generations. It can be reconciled with the findings of Ambler (2015) if husbands and wives already were not acting in a unitary fashion in the home country, or if the relationship between migrants and extended family is already less efficient and less susceptible to change than that between husbands and wives.

\section{Power and External Validity}

We find no significant impact of international migration on risk and time preferences, attitudes towards markets, or the efficiency of transnational household decision-making. Three key concerns are then whether this lack of impact is due to a lack of statistical power or is because Tongan migrants already had preferences and beliefs that are similar to the New Zealand-born, and if neither of these concerns applies the third concern is the extent to which these results might generalize to other settings. We discuss each concern in turn.

\subsection{Statistical Power}

Our sample size consists of 385 individuals for the preference and belief questions and of 282 for the incentivized lotteries and trust games. Are these sample sizes too small to detect meaningful effect sizes? We have four responses to this question. The first is that this is as large a sample as is likely to be possible for such an exercise. Migration lotteries are rare, and even in the absence of lotteries, tracking migrants down over ten years later, and interviewing both them and a partner in different countries is timeconsuming and expensive, and the data we have are unique as a result. Second, the sample sizes we have are not that different from a number of related exercises in the literature. For example, Cameron et al. 
(2013) have 421 individuals for their study of China's one child policy's effects; Chuang and Schechter have data on between 49 and 140 households for their analyses of how shocks affect time and risk preferences, and their survey of 19 studies of risk preference stability in the literature shows a median sample size of 84; Hao et al. (2014) have 144 individuals for their study on migration and risk preferences in China; and di Tella et al. (2007) have 312 households for their study of how property rights affect pro-market beliefs.

Third, we can ask whether large impacts would be consistent with the results we obtain. Considering first the estimates one by one, the standard errors provided in each table allow one to determine the confidence intervals for the different impacts. These confidence intervals typically do not contain the large effect sizes of many of the studies in the literature, but we cannot rule out moderate effects. For example, from Table 3, a 95\% confidence interval for the impact on the 11-point risk-seeking scale is $(-0.27,+0.30)$, and for the likelihood of choosing a risky job is $(-0.14,+0.14)$. Any impact on risk attitudes is therefore relatively modest, and less than the 20 percentage point change seen in Cameron et al. (2013), or the 20 percentage point increase in the likelihood of choosing a risky activity for Hurricane Katrina evacuees (Eckel et al, 2009). For the impact on pro-market beliefs, the 0.53 estimate of di Tella et al. (2007) lies right at the boundary of a 90 percent confidence interval for our LATE impact $(-0.18,0.53)$. A 95 percent confidence interval for the impact on household efficiency in game $A$ is $(-0.03,+0.09)$, which is less than the 16 percentage point change in the amount sent by player 1 in the trust game of Cameron et al. (2013). Finally, we follow Young (2016) in conducting a randomization-inference based omnibus test of overall statistical significance of the 20 outcomes tested in Tables 2, 3 and $6 .{ }^{9}$ His preferred randomization-t method yields a p-value of 0.738 . As a result, we cannot reject that there is no treatment effect whatsoever. In contrast, if we add 0.1 of a standard deviation of the outcomes (typically considered a small effect) to the ballot winner sample, the same test would have a $p$-value of 0 . Likewise if we were to subtract 0.1 of a standard deviation from the ballot winner sample, we would again get an omnibus test $p$-value of 0 . This shows that the omnibus test would reject the null of no treatment effects even if relatively small treatment effect sizes truly were present.

\subsection{Are Tongan Migrants Similar to New Zealanders}

Another potential explanation for why we do not find an impact of migration on preferences and beliefs among Tongan migrants to New Zealand could be if these migrants are already quite similar to New

\footnotetext{
${ }^{9}$ We thank Alwyn Young for sharing code to conduct this test. This procedure also provides randomization-inference $\mathrm{p}$-values for each coefficient. None of these are statistically significant, with the smallest p-value being 0.201 using his randomization-t (or randomization-p) values.
} 
Zealanders either because of cultural proximity or self-selection on these characteristics. Unfortunately, we do not survey New Zealanders and, in general, it is difficult to find representative surveys on preferences and beliefs. However, we have been able to find some evidence that suggest that Tongan PAC migrants are quite different in terms of preferences and beliefs than New Zealanders. For example, the representative 2011 World Values Survey (WVS) asks the same question that we include on general trust (Trusting Others in Table 3). While 70 percent of Tongan migrants in our survey report that most people can be trusted, only 57 percent of non-migrant New Zealanders in the WVS feel the same way. Rieger et al. (2014) and Wang et al. (2016) survey students in 53 countries, including 91 in New Zealand. They ask both time preference and lottery questions similar to the ones we present in Table 2. In their most similar lottery (lottery \#2 in their paper), 24 percent of New Zealand students are risk seekers and 5 percent have severe risk aversion versus only 6 percent of Tongan migrants being risk seekers and 13 percent having severe risk aversion. Similarly, while 75 percent of Tongan migrants are willing to wait one year to receive 1500 NZD instead of 1000 NZD at the current moment, only 45 percent of New Zealand students are willing to wait one month to receive 3800 USD instead of 3400 USD.

\subsection{External Validity}

How much can we expect the results here to generalize to other migration settings? Our setting here considers a common form of international migration - a nuclear household moving from a poor to rich country permanently and leaving extended family behind. To the extent that it differs from other common migration types, it differs in ways which we might think would make it more likely that we would find changes in preferences or beliefs. That is, we would expect any effects to be smaller if migration was more temporary or if it was between countries with more similar income levels, institutions, and levels of economic freedom (as would be the case for migration from one developed economy to another). We would therefore also expect to see no impact of migration on preferences and beliefs in these other migration settings.

\section{Conclusions}

Tongans migrating to New Zealand experience major changes in life circumstances, earning much higher incomes, living in a country with a different culture and more individualistic and market-oriented institutions, and having less interaction with their parents and siblings who remain behind in Tonga. Despite these changes, we find no significant impacts of international migration on the risk and time preferences and pro-market beliefs of these migrants, nor on the efficiency of decision-making with their 
extended household members. These results suggest that, in the case of migration, we can continue to think of decision-making as being based on "deep" parameters of a utility optimization decision that do not change with migration.

These results do contrast with some evidence on large negative shocks and disasters. The literature has speculated that such negative shocks can cause individuals to reappraise their views of the world in which they live. In contrast, international migration provides much more of a positive change in life trajectory, and is a choice made by individuals rather than something forced upon them. This suggests that other large changes in circumstances that are voluntary in nature (e.g. marriage, childbearing, retirement) might also be unlikely to lead to changes in fundamental decision-making parameters. 


\section{References}

Addo, Ping-Ann and Niko Besnier (2008) "When gifts become commodities: Pawnshops, valuables, and shame in Tonga and the Tongan Diaspora", Journal of the Royal Anthropological Institute 14(1): 3959.

Abdulkadiroglu, Atila, Joshua Angrist, Susan Dynarski, Thomas Kane and Parag Pathak (2011) "Accountability and Flexibility in Public Schools: Evidence from Boston's Charters and Pilots." Quarterly Journal of Economics 126(2): 699-748.

Akgüç, Mehtap, Xingfei Liu, Massimiliano Tani, and Klaus F. Zimmermann (2015) "Risk Attitudes and Migration", IZA Discussion Paper no. 9347.

Ambler, Kate (2015) “Don't tell on me: Experimental evidence of Asymmetric Information in Transnational Households", Journal of Development Economics 113: 52-69.

Ashraf, Nava, Diego Aycinea, Claudia Martinez and Dean Yang (2015) "Savings in Transnational Households: A Field Experiment Among Migrants from El Salvador", Review of Economics and Statistics 97(2): 332-51.

Barsky, Robert B, Miles Kimball, F. Thomas Juster and Matthew Shapiro. (1997). "Preference Parameters and Behavioral Heterogeneity: An Experimental Approach in the Health and Retirement Study," Quarterly Journal of Economics 112 (2), 537-79.

Berg, Joyce, John Dickhaut and Kevin McCabe (1995) "Trust, reciprocity, and social history", Games and Economic Behavior, 10(1), 122-142.

Brandts, Jordi and Gary Charness (2011). "The strategy versus the direct-response method: a first survey of experimental comparisons", Experimental Economics, 14(3), 375-398.

Brown, Philip, Adam Daigneault, Emilia Tjernström and Wenbo Zou (2016) “Natural Disasters, Social Protection, and Risk Perceptions," Mimeo.

Callen, Michael, Mohammad Isaqzadeh, James D. Long, and Charles Sprenger (2014) "Violence and Risk Preference: Experimental Evidence from Afghanistan" American Economic Review 104(1):123-48

Cameron, Lisa, N. Erkal, L. Gangadharan and X. Meng (2013) "Little emperors: behavioral impacts of China's One-Child Policy", Science 339, 22 February, 953-957. 
Cameron, Lisa and Manisha Shah (2015) "Risk-taking behavior in the wake of natural disasters", Journal of Human Resources 50(2): 484-515.

Carvalho, Leandro, Stephan Meier and Stephanie Wang (2016) "Poverty and economic decision-making: Evidence from changes in financial resources at payday", American Economic Review 106(2): 260-84.

Casari, Marco and Timothy Cason (2009). "The strategy method lowers measured trustworthy behavior", Economics Letters, 103(3), 157-159.

Charness, Gary, Uri Gneezy and Alex Imas (2013) "Experimental methods: Eliciting risk preferences", Journal of Economic Behavior and Organization 87: 43-51.

Chen, Joyce (2013) "Identifying non-cooperative behavior among spouses: Child outcomes in migrantsending households", Journal of Development Economics 100(1): 1-18.

Chuang, Yating and Laura Schechter (2015) "Stability of experimental and survey measures of risk, time, and social preferences: A review and some new results", Journal of Development Economics 117: 151-70.

De Arcangelis, Giuseppe, Majlinda Joxhe, David McKenzie, Erwin Tiongson and Dean Yang (2015) "Directing remittances to education with soft and hard commitments: Evidence from a lab-in-thefield experiment and new product take-up among Filipino migrants in Rome", Journal of Economic Behavior and Organization 111: 197-208.

De Laat, Joost (2014) "Household allocations and endogenous information: The case of split migrants in Kenya", Journal of Development Economics 106: 108-17.

Dillenberger, David and Kareen Rozen (2015) "History-dependent risk attitude", Journal of Economic Theory 157, 445-477.

Di Tella, Rafael, Sebastian Galiani and Ernesto Schargrodsky (2007) "The formation of beliefs: Evidence from the allocation of land titles to squatters", Quarterly Journal of Economics, 122(1), 209-241.

Dustmann, Christian, Fasani, Francesco, Meng, Xin, and Luigi Minale (2015) “Risk Attitudes and Household Migration Decisions", University College London: Mimeo.

Eckel, Catherine, Mahmoud El- Gambal, and Rick Wilson (2009) "Risk Loving After the Storm: A BayesianNetwork Study of Hurricane Katrina Evacuees." Journal of Economic Behavior and Organization 69(2):110-24 
Eckel, Catherine and Philip Grossman (2002) "Sex differences and statistical stereotyping in attitudes toward financial risk", Evolution and Human Behavior 23 (4): 281-295.

Gibson, John and David McKenzie (2011) "The microeconomic determinants of emigration and return migration of the best and brightest: Evidence from the Pacific", Journal of Development Economics 95: 18-29.

Gibson, John, David McKenzie, Halahingano Rohorua and Steven Stillman (2015) "The Long-term impacts of international migration: Evidence from a lottery", IZA Discussion Paper no. 9492.

Guiso, Luigi, Paola Sapienza and Luigi Zingales (2006) “Does culture affect economic outcomes?”, Journal of Economic Perspectives 20(2): 23-48.

Hao, Li, Daniel Houser, Lei Mao, and Marie Claire Villeval (2014) “A Field Study of Chinese Migrant Workers' Attitudes toward Risks, Strategic Uncertainty, and Competitiveness". IZA Working Paper No. 8227.

Heritage Foundation (2016) Index of Economic Freedom 2016. http://www.heritage.org/index/ranking Jaeger, David, Thomas Dohmen, Armin Falk, David Huffman, Uwe Sunde and Holger Bonin (2010) "Direct Evidence on Risk Attitudes and Migration", Review of Economics and Statistics 92(3): 684-89.

Keasey, Kevin and Philip Moon (1996) "Gambling with the house money in capital expenditure decisions: An experimental analysis," Economics Letters 50(1): 105-110.

Ketu'u, 'Ofa Ki Funga'amangono (2014) “The Impact of Tongan Cultural Practices on Tongan Economic Behaviour", PhD Thesis in Development Studies, University of Auckland.

Krueger, Norris and Peter Dickson (1994) “How Believing in Ourselves Increases Risk Taking: Perceived Self-Efficacy and Opportunity Recognition", Decision Sciences 25(3): 385-400.

Lucas, Robert E. Jr. (1976) “Econometric Policy Evaluation: A Critique" Carnegie-Rochester Conference Series on Public Policy 1: 19-46.

Malmendier, Ulrike and Stefan Nagel (2011) “Depression Babies: do macroeconomic experiences affect risk-taking", Quarterly Journal of Economics 126(1): 373-416. 
McKenzie, David, John Gibson and Steven Stillman (2010) “How Important is Selection? Experimental vs Non-experimental Measures of the Income Gains from Migration" Journal of the European Economic Association, 8(4): 913-45, 2010

Osili, Una Okonkwo and Anna Paulson (2008a) “Institutions and financial development: Evidence from international migrants in the United States", Review of Economics and Statistics 90(3): 498-517.

Osili, Una Okonkwo and Anna Paulson (2008b) "What can we learn about financial access from US immigrants? The role of country of origin institutions and immigrant beliefs", World Bank Economic Review 22(3): 431-55.

Rieger, Marc Oliver, Mei Wang and Thorsten Hens (2014) "Risk Preferences Around the World," Management Science 61(3): 637-648.

Rosenzweig, Mark and Oded Stark (1989) “Consumption smoothing, migration, and marriage: Evidence from rural India", Journal of Political Economy 97(4): 905-26.

Sjaastad, Larry A (1962) “The Costs and Returns of Human Migration." Journal of Political Economy, 70(5): 80-93.

Stark, Oded, and David E. Bloom (1985) "The New Economics of Labor Migration." American Economic Review: Papers and Proceedings, 75(2): 173-178.

Thaler, Richard H. and Eric J. Johnson (1990) "Gambling with the House Money and Trying to Break Even: The Effects of Prior Outcomes on Risky Choice," Management Science 36(6): 643-660.

United Nations Development Program (UNDP) (2015) Human Development Report 2015: Work for Human Development http://hdr.undp.org/sites/default/files/2015 human development report.pdf

Wang, Mei, Marc Oliver Rieger and Thorsten Hens (2016) “How Time Preferences Differ: Evidence from 53 Countries," Journal of Economic Psychology, forthcoming.

Williams, Nathalie, Arland Thornton and Linda Young-DeMarco (2014) “Migrant values and beliefs: How are they different and how do they change?", Journal of Ethnic and Migration Studies 40(5): 796813.

Wolpin, Kenneth (2013) The limits of inference without theory. MIT Press, Cambridge, MA.

World Bank (2016) Migration and Remittances Factbook 2016. World Bank: Washington, D.C. 
Young, Alwyn (2016) “Channeling Fisher: Randomization Tests and the Statistical Insignificance of Seemingly Significant Experimental Results", Mimeo. LSE. 
Figure 1: Sampling Frame

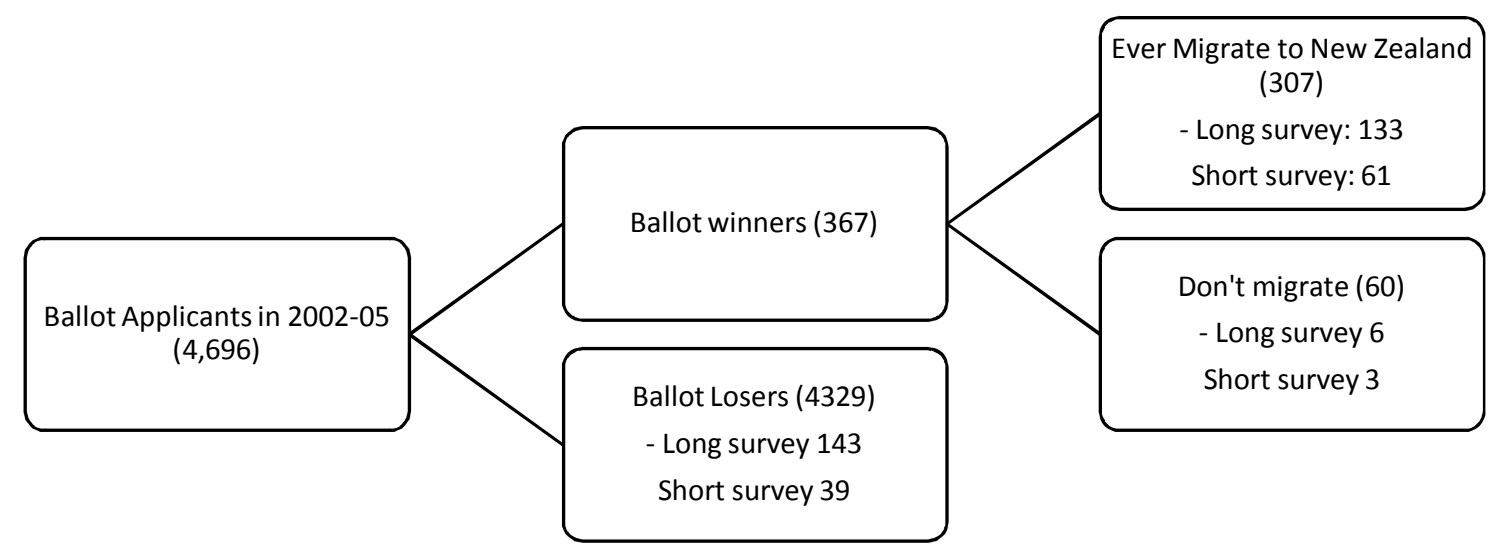

Notes: numbers in parentheses show population numbers. The survey attempted to interview all individuals who migrated to New Zealand by late 2012 when the sample frame was provided; therefore the interview success rate is $64 \%$ (194/307). A random sample of ballot losers and non-compliers (winners who do not migrate) was obtained through village-based sampling. See text for details. 
Figure 2: Household efficiency by treatment status and residual claimant in game

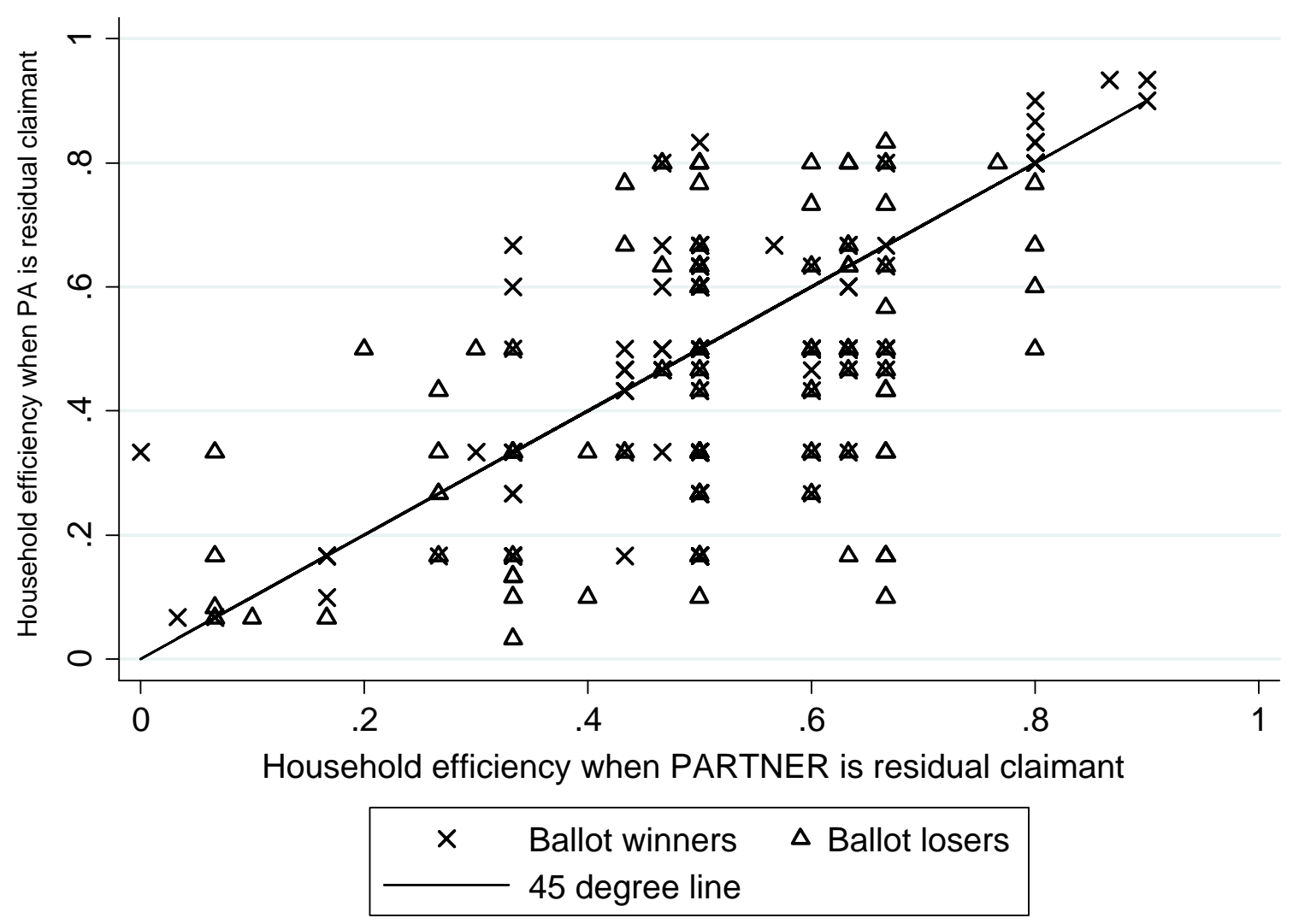

Notes: household efficiency is defined as the proportion of the initial windfall that is transferred to the bonus pot in the trust game. Y-axis shows efficiency in game $A$, where the principal applicant (PA) receives all the money in the bonus pot; $X$-axis shows efficiency in game $B$, where the partner receives all the money in the bonus pot. Ballot winners and ballot losers denote households which won and lost the Pacific Access Category migrant lottery respectively. 
Figure 3: Household efficiency by treatment status and information availability to partner

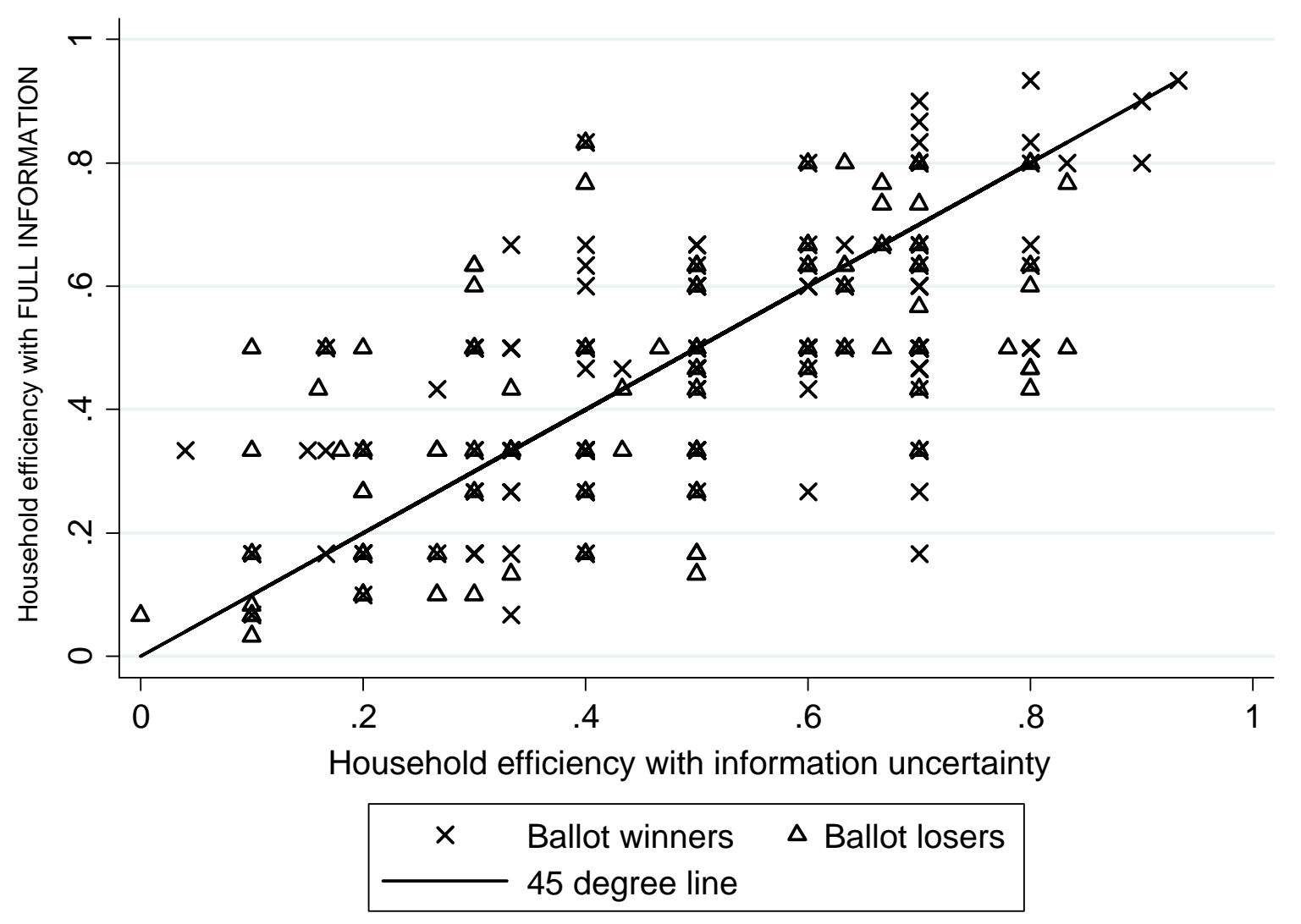

Notes: household efficiency is defined as the proportion of the initial windfall that is transferred to the bonus pot in the trust game. Y-axis shows efficiency in game $A$, where the principal applicant (PA) receives all the money in the bonus pot and the partner household has full information on PA's actions; X-axis shows efficiency in game $\mathrm{C}$, where the principal applicant receives all the money in the bonus pot, but where the partner only observes how much the PA transfers, but does not know their initial windfall. Ballot winners and ballot losers denote households which won and lost the Pacific Access Category migrant lottery respectively. 
Table 1: Summary Statistics of Principal Applicants by Treatment Group

\begin{tabular}{lccccccc}
\hline & \multicolumn{3}{c}{ Ballot Winners } & \multicolumn{3}{c}{ Ballot Losers } \\
& $\mathrm{N}$ & Mean & S.D. & $\mathrm{N}$ & Mean & S.D. & P-value \\
\hline $\begin{array}{l}\text { Pre-determined Characteristics } \\
\text { Age }\end{array}$ & 203 & 40.1 & 7.0 & 182 & 41.8 & 7.0 & 0.045 \\
Male & 203 & 0.66 & 0.49 & 182 & 0.67 & 0.47 & 0.814 \\
Born in Outer Islands & 203 & 0.23 & 0.43 & 182 & 0.24 & 0.43 & 0.973 \\
Height (cm) & 139 & 171.6 & 5.2 & 143 & 171.7 & 5.2 & 0.875 \\
Characteristics that can change with migration & & & & & & \\
Years of Schooling & 203 & 13.1 & 1.4 & 182 & 12.2 & 1.8 & 0.000 \\
Tertiary Education & 203 & 0.37 & 0.49 & 182 & 0.18 & 0.39 & 0.000 \\
Weekly Earnings (NZD) & 203 & 410 & 367 & 182 & 126 & 140 & 0.000 \\
Household Size & 203 & 5.05 & 2.25 & 182 & 5.26 & 1.99 & 0.330 \\
Years in New Zealand & 133 & 9.20 & 1.25 & & & & \\
\hline
\end{tabular}

Notes:

Weighted mean for ballot winners shown, which accounts for different sampling rate of migrants and non-compliers. P-value is for test of equality of means. Height and Years in New Zealand only asked in long-form survey. Years in New Zealand is conditional on ever migrating. 


\begin{tabular}{|c|c|c|c|c|c|c|c|c|c|c|}
\hline & $\begin{array}{c}\text { Risk-seeking } \\
\text { scale }\end{array}$ & $\begin{array}{c}\text { Take } \\
\text { Risky Job }\end{array}$ & $\begin{array}{c}\text { Inefficient } \\
\text { Decision }\end{array}$ & $\begin{array}{c}\text { Severe } \\
\text { Risk Aversion }\end{array}$ & $\begin{array}{c}\text { Risk } \\
\text { Seeker }\end{array}$ & $\begin{array}{c}\text { Aggregate } \\
\text { Risk-Seeking } \\
\text { Index }\end{array}$ & $\begin{array}{c}\text { High } \\
\text { Discount } \\
\text { Rate } \\
\end{array}$ & $\begin{array}{l}\text { Hyperbolic } \\
\text { Discounter }\end{array}$ & $\begin{array}{c}\text { Short-term } \\
\text { Planner }\end{array}$ & $\begin{array}{c}\text { Aggregate } \\
\text { Short-termism } \\
\text { Index } \\
\end{array}$ \\
\hline \multicolumn{11}{|c|}{ Panel A: ITT Impact } \\
\hline Ballot Winner & $\begin{array}{c}0.014 \\
(0.106)\end{array}$ & $\begin{array}{c}0.001 \\
(0.070)\end{array}$ & $\begin{array}{l}-0.084 \\
(0.077)\end{array}$ & $\begin{array}{c}0.095 \\
(0.072)\end{array}$ & $\begin{array}{c}0.000 \\
(0.036)\end{array}$ & $\begin{array}{l}-0.109 \\
(0.084)\end{array}$ & $\begin{array}{l}-0.035 \\
(0.061)\end{array}$ & $\begin{array}{c}0.031 \\
(0.060)\end{array}$ & $\begin{array}{c}0.023 \\
(0.082)\end{array}$ & $\begin{array}{l}-0.024 \\
(0.130)\end{array}$ \\
\hline \multicolumn{11}{|c|}{ Panel B: LATE Impact } \\
\hline Migrate & $\begin{array}{c}0.020 \\
(0.146)\end{array}$ & $\begin{array}{c}0.001 \\
(0.097)\end{array}$ & $\begin{array}{l}-0.112 \\
(0.104)\end{array}$ & $\begin{array}{c}0.128 \\
(0.102)\end{array}$ & $\begin{array}{c}0.000 \\
(0.049)\end{array}$ & $\begin{array}{l}-0.147 \\
(0.123)\end{array}$ & $\begin{array}{l}-0.049 \\
(0.083)\end{array}$ & $\begin{array}{c}0.042 \\
(0.081)\end{array}$ & $\begin{array}{c}0.031 \\
(0.109)\end{array}$ & $\begin{array}{l}-0.032 \\
(0.176)\end{array}$ \\
\hline Sample Size & 384 & 385 & 282 & 282 & 282 & 282 & 385 & 282 & 282 & 282 \\
\hline Control Mean & 6.210 & 0.522 & 0.392 & 0.133 & 0.063 & 0.007 & 0.253 & 0.133 & 0.748 & -0.008 \\
\hline Control S.D. & 0.907 & 0.501 & 0.490 & 0.341 & 0.244 & 0.499 & 0.436 & 0.341 & 0.436 & 0.659 \\
\hline
\end{tabular}

Notes:
Robust standard errors in parentheses: ${ }^{*}, * *, * * *$ indicate significance at the 10,5 , and 1 percent levels respectively.

Regressions weighted for population proportions of compliers and non-compliers, and include controls for age, gender, island of birth, ballot years, and survey form (long or short).

Risk-seeking scale is self-assessed on a scale from 0 to 10 , with higher scores reflecting more willingness to take risks; take risky job indicates they would give up a safe job for a riskier one with a chance of higher income; inefficient decision indicates they make an inefficient decision in an incentivized risk preferences game; severe risk aversion and risk-seeker indicate making a choice in the incentivized risk preference game that corresponds to a coefficient of relative risk aversion above one or below zero respectively; aggregate risk-seeking index is an standardized index of the different risk preference measures, with higher scores indicating more risk-seeking; high discount rate indicates they prefer NZ\$1000 today to NZ\$1500 in one year in a hypothetical choice; hyperbolic discounter indicates they have a higher discount rate when comparing today to one year than one year to two years in a hypothetical choice; short-term planner indicates they make choices over the next week; and aggregate short-termism index is a standardized index of the different time preference measures. See appendix 1 for more details on each variable. 
Table 3: Impact on Pro-market Beliefs

\begin{tabular}{lccccc}
\hline & $\begin{array}{c}\text { Success } \\
\text { Alone }\end{array}$ & $\begin{array}{c}\text { Money } \\
\text { Important }\end{array}$ & $\begin{array}{c}\text { Effort } \\
\text { Better }\end{array}$ & $\begin{array}{c}\text { Trust } \\
\text { Others }\end{array}$ & $\begin{array}{c}\text { Market } \\
\text { Beliefs }\end{array}$ \\
\hline $\begin{array}{l}\text { Panel A: ITT Impact } \\
\text { Ballot Winner }\end{array}$ & -0.010 & 0.054 & 0.005 & 0.078 & 0.127 \\
& $(0.051)$ & $(0.068)$ & $(0.075)$ & $(0.059)$ & $(0.152)$ \\
Panel B: LATE Impact & & & & & \\
Migrate & -0.014 & 0.076 & 0.006 & 0.109 & 0.177 \\
& $(0.070)$ & $(0.096)$ & $(0.104)$ & $(0.085)$ & $(0.217)$ \\
Sample Size & 385 & 385 & 385 & 385 & 385 \\
Control Mean & 0.808 & 0.280 & 0.418 & 0.703 & 2.209 \\
Control Std. Dev. & 0.395 & 0.450 & 0.495 & 0.458 & 1.072 \\
\hline Notes: & & & & &
\end{tabular}

Robust standard errors in parentheses: $*, * *, * * *$ indicate significance at the 10,5 , and 1 percent levels respectively.

Regressions weighted for population proportions of compliers and non-compliers, and include controls for age, gender, island of birth, ballot years, and survey form (long or short).

Success Alone denotes the individual believes you can be successful on your own; money important denotes they believe money is very important for happiness; effort better denotes they believe those who put in effort working are much better off; trust others denotes they believe others can be trusted; and market beliefs is the sum of these four variables. See appendix 1 for more on these variables. 
Table 4: Descriptive Statistics on Partners by Treatment Group

\begin{tabular}{lcccccccc}
\hline & \multicolumn{3}{c}{ Ballot Winners } & \multicolumn{3}{c}{ Ballot Losers } \\
& $\mathrm{N}$ & Mean & S.D. & $\mathrm{N}$ & Mean & S.D. & P-value \\
\hline Partner is Their Parent & 139 & 0.40 & 0.49 & 143 & 0.46 & 0.50 & 0.338 \\
Partner is Their Sibling & 139 & 0.60 & 0.49 & 143 & 0.54 & 0.50 & 0.338 \\
Partner's Age & 139 & 52.1 & 12.9 & 143 & 56.2 & 12.3 & 0.008 \\
Partner Female & 139 & 0.57 & 0.50 & 143 & 0.64 & 0.48 & 0.269 \\
Partner's Years of Schooling & 139 & 11.4 & 1.9 & 143 & 11.2 & 2.3 & 0.426 \\
Partner has Tertiary Education & 139 & 0.13 & 0.34 & 143 & 0.18 & 0.39 & 0.314 \\
Partner is Employed & 139 & 0.42 & 0.49 & 143 & 0.35 & 0.48 & 0.299 \\
Partner's Weekly Earnings (NZD) & 139 & 63 & 85 & 143 & 60 & 92 & 0.787 \\
Partner's Household Income (NZD) & 139 & 129 & 140 & 143 & 150 & 143 & 0.238 \\
\hline
\end{tabular}

Notes:

Weighted mean for ballot winners shown, which accounts for different sampling rate of migrants

and non-compliers. P-value is for test of equality of means. Partner refers to person chosen for trust game. 
Table 5: Impact on Interaction with Partner

\begin{tabular}{|c|c|c|c|c|c|c|c|c|c|c|c|}
\hline & $\begin{array}{c}\text { Communicate } \\
\text { Weekly }\end{array}$ & $\begin{array}{c}\text { Send mon } \\
\text { several } \\
\text { times } \\
\end{array}$ & $\begin{array}{l}\text { seive mon } \\
\text { several } \\
\text { times }\end{array}$ & $\begin{array}{l}\text { Would trust } \\
\text { partner } \\
\text { with loan } \\
\end{array}$ & $\begin{array}{c}\text { Knows } \\
\text { partner's } \\
\text { earnings }\end{array}$ & $\begin{array}{c}\text { Partner } \\
\text { knows } \\
\text { PA's earnings }\end{array}$ & $\begin{array}{c}\text { Consults with } \\
\text { partner } \\
\text { on finances }\end{array}$ & $\begin{array}{c}\text { Partner consults } \\
\text { them on } \\
\text { finances }\end{array}$ & $\begin{array}{c}\text { Joint } \\
\text { Business }\end{array}$ & $\begin{array}{c}\text { Joint } \\
\text { Livestock }\end{array}$ & $\begin{array}{c}\text { Aggregate } \\
\text { Interactions } \\
\text { Index } \\
\end{array}$ \\
\hline \multicolumn{12}{|c|}{ Panel A: ITT Impact } \\
\hline Ballot Winner & $\begin{array}{c}-0.257^{* * *} \\
(0.075)\end{array}$ & $\begin{array}{c}0.034 \\
(0.096)\end{array}$ & $\begin{array}{c}-0.448^{* * *} \\
(0.045)\end{array}$ & $\begin{array}{c}0.158^{* * *} \\
(0.037)\end{array}$ & $\begin{array}{c}0.014 \\
(0.025)\end{array}$ & $\begin{array}{c}-0.075^{* *} \\
(0.033)\end{array}$ & $\begin{array}{c}-0.254^{* * *} \\
(0.083)\end{array}$ & $\begin{array}{c}0.074 \\
(0.092)\end{array}$ & $\begin{array}{l}-0.072 \\
(0.078)\end{array}$ & $\begin{array}{c}0.165^{* * *} \\
(0.050)\end{array}$ & $\begin{array}{l}-0.138^{*} \\
(0.070)\end{array}$ \\
\hline \multicolumn{12}{|c|}{ Panel B: LATE Impact } \\
\hline Migrate & $\begin{array}{c}-0.345^{* * *} \\
(0.094)\end{array}$ & $\begin{array}{c}0.046 \\
(0.125)\end{array}$ & $\begin{array}{c}-0.603^{* * *} \\
(0.099)\end{array}$ & $\begin{array}{c}0.212^{* * *} \\
(0.058)\end{array}$ & $\begin{array}{c}0.019 \\
(0.033)\end{array}$ & $\begin{array}{c}-0.101^{* *} \\
(0.049)\end{array}$ & $\begin{array}{c}-0.341^{* * *} \\
(0.115)\end{array}$ & $\begin{array}{c}0.099 \\
(0.120)\end{array}$ & $\begin{array}{l}-0.096 \\
(0.102)\end{array}$ & $\begin{array}{c}0.222^{* * *} \\
(0.076)\end{array}$ & $\begin{array}{l}-0.186^{*} \\
(0.103)\end{array}$ \\
\hline Sample Size & 282 & 282 & 282 & 282 & 282 & 282 & 282 & 282 & 282 & 282 & 282 \\
\hline Control Mean & 0.769 & 0.720 & 0.448 & 0.804 & 0.021 & 0.105 & 0.538 & 0.545 & 0.413 & 0.741 & 0.077 \\
\hline Control Std Dev & 0.423 & 0.450 & 0.499 & 0.398 & 0.144 & 0.307 & 0.500 & 0.500 & 0.494 & 0.439 & 0.651 \\
\hline
\end{tabular}

Notes: Robust standard errors in parentheses. ${ }^{*}, * *$, and ${ }^{* * *}$ indicate significance at the 10,5 , and 1 percent levels respectively.

Regressions weighted for population proportions of compliers and non-compliers, and include controls for age, gender, island of birth, and ballot years.

Outcomes are all binary variables indicating that principal applicant (PA) and partner communicate weekly, that PA sends money to partner at least several times per year, that

PA receives money from partner at least several times per year, that PA would trust partner to return a possession loaned, that PA says they know the partner's earnings, that

the PA thinks the partner knows the PA's earnings, that the PA consults with the partner on finances, that the partner consults with them on finances, and that the PA and

partner jointly own a business or livestock together. Partner is the parent or sibling of the principal applicant chosen for household decision-making game. Aggregate

interactions index is an index of standardized $z$-scores of these variables, with a higher value indicating more communication. 
Table 6: Impact on Household Efficiency in Trust Game

\begin{tabular}{lccccc}
\hline & \multicolumn{3}{c}{ Household Efficiency in: } & \multicolumn{2}{c}{ Efficiency Gap: } \\
& Game A & Game B & Game C & A-B & A-C \\
\hline $\begin{array}{l}\text { Panel A: ITT Impact } \\
\text { Ballot Winner }\end{array}$ & 0.034 & 0.026 & 0.037 & 0.009 & -0.003 \\
& $(0.031)$ & $(0.022)$ & $(0.027)$ & $(0.029)$ & $(0.026)$ \\
Panel B: LATE Impact & & & & & \\
Migrate & 0.044 & 0.033 & 0.048 & 0.011 & -0.003 \\
& $(0.041)$ & $(0.030)$ & $(0.036)$ & $(0.038)$ & $(0.033)$ \\
Sample Size & 282 & 282 & 282 & 282 & 282 \\
Control Mean & 0.465 & 0.508 & 0.482 & -0.043 & -0.018 \\
Control Std Dev & 0.205 & 0.150 & 0.216 & 0.188 & 0.168 \\
\hline Notes: & & & & &
\end{tabular}

Robust standard errors in parentheses: ${ }^{*}, * *, * * *$ indicate significance at the 10,5 , and 1 percent levels respectively.

Regressions weighted for population proportions of compliers and non-compliers, and include controls for age, gender, island of birth, ballot years, game order, partner age, partner gender, and whether the partner is the parent of the principal applicant.

Game A has full information and the principal applicant (PA) as the claimant on the bonus pot; Game B has full information and the partner as the claimant on the bonus pot; Game $C$ has the principal applicant as the claimant on the bonus pot, but partial information, with the partner only observing how much the PA transfers, not how much they start with. Household efficiency is the share of the windfall transferred to the bonus pot. 
Table 7: What factors are associated with greater transnational household efficiency?

Dependent Variable: Household Efficiency in Game A

Dependent Variable: Household Efficiency in Game A

Principal Applicant Age

Principal Applicant is Male

Principal Applicant from Outer Islands

Principal Applicant's Years of Schooling

Principal Applicant's Earnings

Partner is Parent of PA

Partner is Female

Partner's Years of Schooling

Would trust other player if lent possessions

Communicates weekly with other player

Sends money to other player several times a year

Typically consults with partner on financial decisions

Partner typically consults with PA on financial decisions

Jointly own a business together

\begin{tabular}{|c|c|c|c|c|c|c|}
\hline (1) & (2) & (3) & (4) & (5) & (6) & (7) \\
\hline 0.002 & $0.003 * *$ & 0.002 & 0.003* & $0.003 * *$ & 0.003* & $0.004^{* *}$ \\
\hline$(0.002)$ & $(0.002)$ & $(0.002)$ & $(0.002)$ & $(0.002)$ & $(0.002)$ & $(0.002)$ \\
\hline-0.010 & -0.001 & -0.009 & -0.009 & -0.011 & -0.018 & -0.015 \\
\hline$(0.024)$ & $(0.024)$ & $(0.024)$ & $(0.024)$ & $(0.024)$ & $(0.023)$ & $(0.024)$ \\
\hline $0.052^{*}$ & 0.044 & $0.052^{*}$ & $0.052 *$ & $0.051^{*}$ & 0.027 & 0.044 \\
\hline$(0.030)$ & $(0.028)$ & (0.031) & $(0.030)$ & $(0.030)$ & $(0.030)$ & $(0.029)$ \\
\hline $0.025 * * *$ & $0.017^{* *}$ & $0.024 * * *$ & $0.022 * * *$ & $0.019 * *$ & $0.015^{* *}$ & 0.012 \\
\hline$(0.008)$ & $(0.008)$ & $(0.008)$ & $(0.008)$ & $(0.008)$ & $(0.007)$ & $(0.009)$ \\
\hline-0.000 & -0.000 & -0.000 & -0.000 & -0.000 & 0.000 & -0.000 \\
\hline$(0.000)$ & $(0.000)$ & $(0.000)$ & $(0.000)$ & $(0.000)$ & $(0.000)$ & $(0.000)$ \\
\hline $0.082 * * *$ & 0.032 & $0.074 * *$ & $0.067 * *$ & 0.036 & $0.061 * *$ & 0.011 \\
\hline$(0.028)$ & (0.029) & $(0.030)$ & $(0.029)$ & $(0.028)$ & $(0.027)$ & $(0.030)$ \\
\hline 0.022 & 0.004 & 0.022 & 0.020 & 0.024 & 0.017 & 0.015 \\
\hline$(0.023)$ & $(0.022)$ & $(0.023)$ & $(0.024)$ & $(0.023)$ & $(0.022)$ & $(0.022)$ \\
\hline $0.016^{* *}$ & $0.012^{*}$ & $0.016^{* *}$ & $0.019 * * *$ & $0.017^{* *}$ & $0.012 *$ & $0.013^{*}$ \\
\hline \multirow[t]{12}{*}{$(0.007)$} & $(0.007)$ & $(0.007)$ & $(0.007)$ & $(0.007)$ & $(0.006)$ & $(0.007)$ \\
\hline & $0.195^{* * *}$ & & & & & \\
\hline & (0.031) & & & & & \\
\hline & & 0.015 & & & & \\
\hline & & $(0.030)$ & & & & \\
\hline & & & $0.068 *$ & & & \\
\hline & & & $(0.038)$ & & & \\
\hline & & & & 0.004 & & \\
\hline & & & & (0.030) & & \\
\hline & & & & $0.108 * * *$ & & \\
\hline & & & & $(0.029)$ & & \\
\hline & & & & & $0.144^{* * *}$ & \\
\hline
\end{tabular}


Notes: Robust standard errors in parentheses. $*, * *$, and $* * *$ indicate significance at the 10,5 , and 1 percent levels respectively.

Household Efficiency in Game A is the share of the initial windfall that ends up getting transferred by the player and their partner into the bonus pot, with a higher share indicating greater efficiency. Coefficients shown are regression estimates, pooling together the ballot winner and ballot loser samples. 


\section{Appendix 1: Variable Definitions}

\section{$\underline{\text { Risk preference measures }}$}

Risk-seeking score: is a score based on the respondent's rating of themselves on an 11-point scale from 0 to 10 , where 0 is unwilling to take risks, and 10 is fully prepared to take risks. This is based on the selfassessed risk preference question from the German Socio-economic Panel (Jaeger et al, 2010).

Take Risky Job: is a binary variable indicating that the individual would choose to take a new job that, with a 50-50 chance would double their current income, and a 50:50 chance would cut their income by 20 percent. This is based on the question used in the Health and Retirement Study and analyzed by Barsky et al. (1997).

Inefficient Decision, Severe Risk Aversion, and Risk-Seeker are based on the individual's choices in an incentivized game. Individuals were asked to choose one of the businesses from the list of $\mathrm{A}$ through $\mathrm{H}$ below. Each business differs in terms of how many Pa'anga it pays out in a good month and how many in a less good month, but in all other regards the businesses are the same. They were told a coin would be tossed and they will receive the amount of money in the Heads column if it comes up heads (a less good month), and the amount in the Tails column if it comes up tails (the good month). They were not shown the expected return, standard deviation, or implied coefficient of relative risk aversion for each game. This game is based on the approach of Eckel and Grossman (2002), but modified to be framed in terms of businesses in case individuals had religious objections to gambling.

\begin{tabular}{cccccl}
\hline Business & Heads & Tails & $\begin{array}{c}\text { Expected } \\
\text { Return }\end{array}$ & $\begin{array}{c}\text { Std. } \\
\text { Dev. }\end{array}$ & $\begin{array}{l}\text { Implied } \\
\text { CRRA range }\end{array}$ \\
\hline A & 10 & 10 & 10 & 0 & $7.5<r$ \\
B & 9 & 19 & 14 & 5 & $1<r<7.5$ \\
C & 8 & 24 & 16 & 8 & $0.85<r<1$ \\
D & 7 & 25 & 16 & 9 & inefficient \\
E & 6 & 30 & 18 & 12 & $0.315<r<0.85$ \\
F & 4 & 32 & 18 & 14 & inefficient \\
G & 2 & 38 & 20 & 18 & $0<r<0.315$ \\
H & 0 & 40 & 20 & 20 & $r<0$ \\
\hline
\end{tabular}

We created three dummy variables based on response choices to this game. Individuals made an Inefficient Decision if they chose business D or F. To see this, note that businesses $\mathrm{D}$ and $\mathrm{F}$ have the same expected return as other businesses in the game ( $C$ and $E$ respectively) but higher standard deviations. An 
individual should therefore only prefer $D$ to $C$ or $F$ to $E$ if they are risk-seeking. But if they are risk-seeking, they should prefer business $\mathrm{H}$ which has a higher expected return to business $\mathrm{D}$ or F. Severe Risk Aversion was coded as an individual choosing businesses A or B, which have implied coefficients of relative risk aversion above 1. Risk-Seeker denotes that the individual choose business $\mathrm{H}$.

Aggregate Risk-Seeking Index is the average of the standardized z-scores for the following four risk measures which were signed so that for each a higher number indicates more risk-seeking (risk-seeking score, take risky job, severe risk aversion (reverse-signed), and risk-seeker).

\section{$\underline{\text { Time preference measures }}$}

High discount rate indicates that an individual would prefer to receive NZ\$1000 today than NZ\$1500 one year from today when asked a hypothetical choice.

Hyperbolic discounter indicates the individual has a higher discount rate when comparing today to one year than comparing one year to two years when asked hypothetical choices about amounts to be received at different dates.

Short-term planner indicates that when the individual was asked the time period that best describes the period most important to them in making financial decisions about saving and spending, they answered "the next week" as compared to longer term horizons.

Aggregate Short-termism index is the average of standardized z-scores for each of the three time preference measures (high discount rate, hyperbolic discounter, and short-term planner), with higher scores indicating the individual is more short-term in their decision-making orientation.

\section{Pro-market belief measures}

Our measures of pro-market beliefs come from questions that follow di Tella et al. (2007).

Success alone is a binary variable coded as one if the individual believes it is possible to be successful on your own versus that a large group is necessary to be successful.

Money important is a binary variable coded as one if the individual believes money is indispensable to being happy. Note this differs from the coding of di Tella et al. (2007) who also include the responses "it is very important" and "it is important" as one, versus "it is not important to being happy". We had no responses of "it is not important to being happy" so this variable would be degenerate if coded as they did. 
Effort better is a binary variable coded as one if the individual believes that people who put effort into working end up much better off than those who do not put in an effort. This differs from the coding of di Tella et al. (2007) who also include "better off" as one, versus "worse off" and "much worse off". No one responds "much worse off" in our survey, and only 3 percent respond "worse off", so the dichotomy here is between "much better" versus "better".

Trust others is a binary variable coded as one if the individual believes you can trust others versus that you cannot trust others.

Market beliefs is the sum of the four binary variables of pro-market beliefs.

\section{$\underline{\text { Interaction with Partner Household }}$}

Communicate Weekly is a binary variable coded as one if the principal applicant says that they communicate at least weekly with the player in the partner household.

Send money several times is a binary variable coded as one if the principal applicant says that they send money to the partner household at least several times a year (the question gave options of at least monthly, several times a year, once a year, less than once a year or never, and only $2 \%$ of ballot winners and $4 \%$ of ballot losers send money monthly).

Receive money several times is a binary variable coded as one if the principal applicant says that they receive money from the partner household at least several times a year.

Would trust partner loan is a binary variable indicating that the principal applicant says that they would trust the partner to return a possession that they lent to them without having to ask repeatedly for it to be returned.

Know partner earnings is a binary variable indicating that the principal applicant says that they know how much the partner earns from work each month.

Partner knows PA's earnings is a binary variable indicating that the principal applicant says that the partner knows how much the principal applicant (PA) earns from work each month.

Consults with partner on finances is a binary variable indicating that the principal applicant says that they typically consult with the partner before making financial decisions.

Partner consults them on finances is a binary variable indicating that the principal applicant says that the partner typically consults the principal applicant before making financial decisions. 
Joint business is a binary variable indicating that the principal applicant and partner jointly own a business together

Joint livestock is a binary variable indicating that the principal applicant and partner jointly own livestock together.

Aggregate interactions index is the average of the standardized z-scores of these 10 measures of interaction between the principal applicant and the partner household.

\section{Household Efficiency in the Trust Game}

Three versions of the trust game were given to each applicant-partner dyad, with the order randomized. The versions differ in how money is divided between players and in the information available to each player. Version A of the trust game has full information and the principal applicant as the residual claimant, with the following instructions:

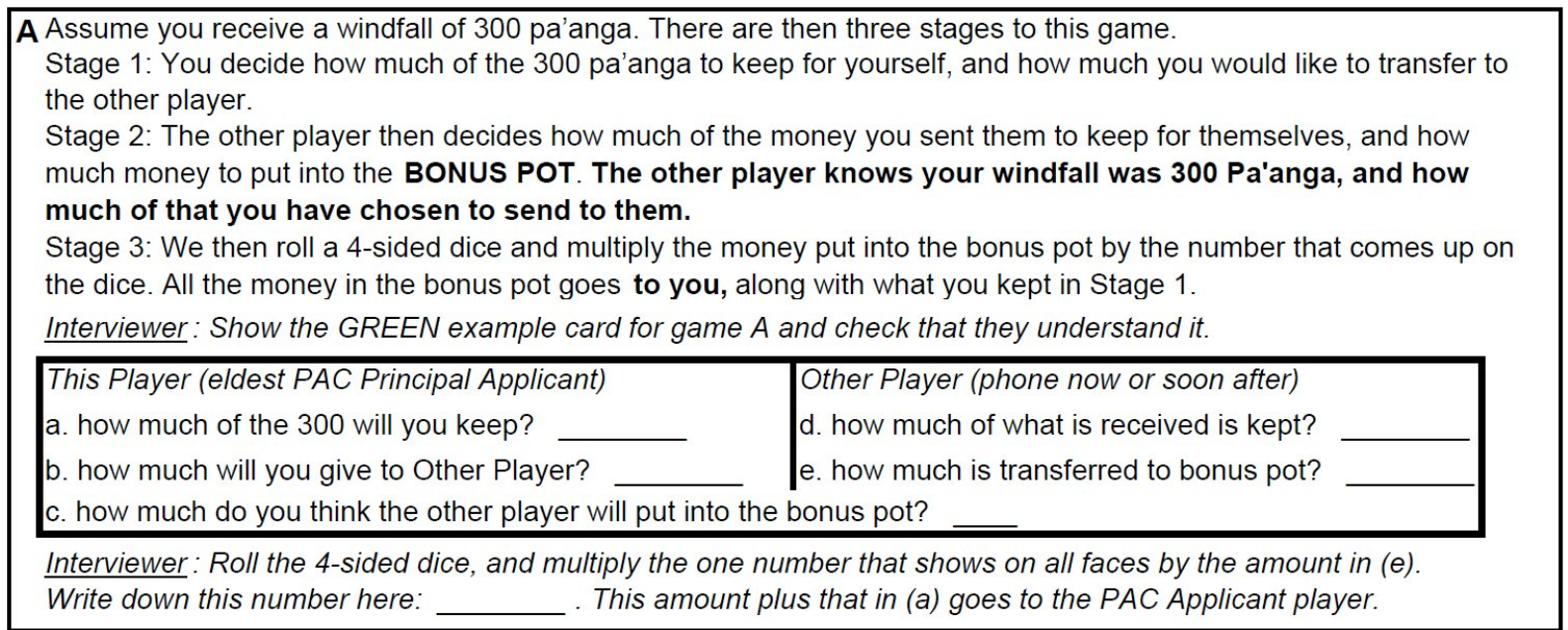

Household efficiency in game A is then defined as the share of the available windfall in this game (300 pa'anga) transferred to the bonus pot (sub-question e).

Version B of the game has full information and the partner as the residual claimant: 


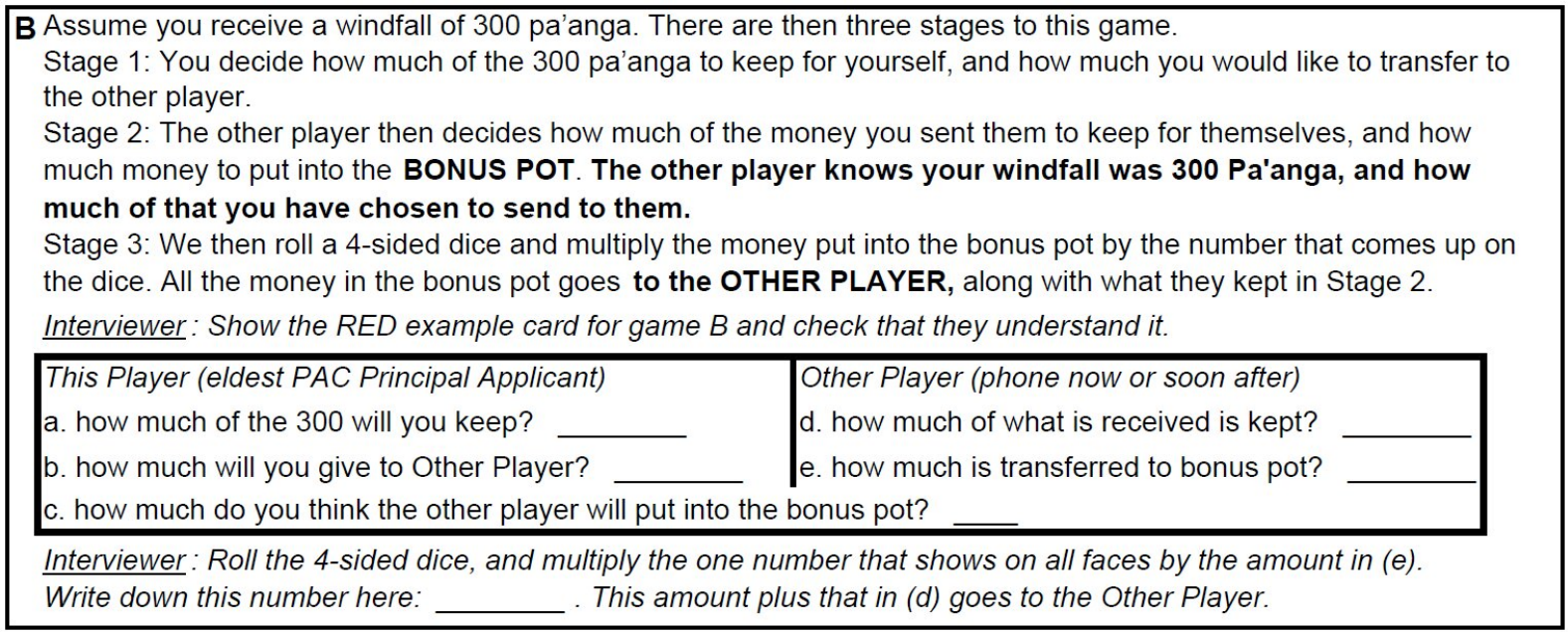

Household efficiency in game B is then again defined as the share of the windfall in this game transferred to the bonus pot.

Version $\mathrm{C}$ of the game again has the principal applicant as the residual claimant, but has partial information, with the partner not knowing exactly what the windfall received by the principal applicant was:

Interviewer: In version C of the game, the PAC Applicant player draws a number from a hat, which is either 100, 300 or 500 . This is the amount of windfall $(\boldsymbol{W})$ for this game. The other player is not told how much $\boldsymbol{W}$ is.

C Assume you receive a windfall of $\mathbf{W}$ pa'anga. There are then three stages to this game.

Stage 1: You decide how much of the $\mathbf{W}$ pa'anga to keep for yourself, and how much you would like to transfer to the other player.

Stage 2: The other player then decides how much of the money you sent them to keep for themselves, and how much money to put into the BONUS POT. The other player only knows your windfall was somewhere between 100 and $500 \mathrm{~Pa}$ anga but not the exact amount.

Stage 3: We then roll a 4-sided dice and multiply the money put into the bonus pot by the number that comes up on the dice. All the money in the bonus pot goes to YOU, along with what you kept in Stage 1.

Interviewer: Show the BLUE example card for game $C$ and check that they understand it.

\begin{tabular}{|l|l|}
\hline This Player (eldest PAC Principal Applicant) & $\begin{array}{l}\text { Other Player (phone now or soon after) } \\
\text { a. how much of the } \mathbf{W} \text { will you keep? }\end{array}$ \\
$\begin{array}{l}\text { b. how much will you give to Other Player? } \\
\text { c. how much do you think the other player will put into the bonus pot? }\end{array}$ \\
\hline
\end{tabular}

Interviewer: Roll the 4-sided dice, and multiply the one number that shows on all faces by the amount in (e). Write down this number here: . This amount plus that in (a) goes to the PAC Applicant Player.

Household efficiency in game $\mathrm{C}$ is defined as the share of the windfall $\mathrm{W}$ that is transferred to the bonus pot.

Efficiency gap $A-B$ is household efficiency in game A minus household efficiency in game B.

Efficiency gap A-C is household efficiency in game A minus household efficiency in game C. 
Appendix 2: Individual Player Behavior in Trust Game

\begin{tabular}{|c|c|c|c|c|c|}
\hline & $\begin{array}{c}\text { Sample } \\
\text { Size }\end{array}$ & $\begin{array}{c}\text { Control } \\
\text { Mean }\end{array}$ & $\begin{array}{c}\text { Control } \\
\text { S.D. }\end{array}$ & $\begin{array}{c}\text { ITT } \\
\text { Impact }\end{array}$ & $\begin{array}{c}\text { LATE } \\
\text { Impact }\end{array}$ \\
\hline Share kept by $P A$ in game $A$ & 282 & 0.405 & 0.182 & $\begin{array}{c}-0.038 \\
(0.027)\end{array}$ & $\begin{array}{c}-0.050 \\
(0.035)\end{array}$ \\
\hline Share kept by $P A$ in game $B$ & 282 & 0.359 & 0.144 & $\begin{array}{c}-0.014 \\
(0.021)\end{array}$ & $\begin{array}{c}-0.018 \\
(0.027)\end{array}$ \\
\hline Share kept by PA in game $C$ & 282 & 0.373 & 0.203 & $\begin{array}{c}-0.052 * * \\
(0.026)\end{array}$ & $\begin{array}{c}-0.068 * * \\
(0.034)\end{array}$ \\
\hline PA share in A - PA share in $B$ & 282 & 0.046 & 0.205 & $\begin{array}{c}-0.024 \\
(0.029)\end{array}$ & $\begin{array}{c}-0.032 \\
(0.038)\end{array}$ \\
\hline PA share in $A$ - PA share in $C$ & 282 & -0.032 & 0.187 & $\begin{array}{c}-0.014 \\
(0.029)\end{array}$ & $\begin{array}{c}-0.018 \\
(0.038)\end{array}$ \\
\hline Share kept by partner in game $A$ & 282 & 0.245 & 0.192 & $\begin{array}{l}-0.016 \\
(0.030)\end{array}$ & $\begin{array}{l}-0.020 \\
(0.038)\end{array}$ \\
\hline Share kept by partner in game B & 282 & 0.218 & 0.144 & $\begin{array}{l}-0.026 \\
(0.024)\end{array}$ & $\begin{array}{l}-0.033 \\
(0.033)\end{array}$ \\
\hline Share kept by partner in game $C$ & 282 & 0.255 & 0.184 & $\begin{array}{c}-0.004 \\
(0.023)\end{array}$ & $\begin{array}{l}-0.005 \\
(0.029)\end{array}$ \\
\hline Share PA expected partner to keep in game A & 282 & 0.425 & 0.177 & $\begin{array}{c}0.009 \\
(0.022)\end{array}$ & $\begin{array}{c}0.012 \\
(0.029)\end{array}$ \\
\hline Share PA expected partner to keep in game B & 281 & 0.422 & 0.188 & $\begin{array}{l}-0.019 \\
(0.024)\end{array}$ & $\begin{array}{c}-0.024 \\
(0.031)\end{array}$ \\
\hline Share PA expected partner to keep in game C & 282 & 0.418 & 0.173 & $\begin{array}{c}-0.031 \\
(0.030)\end{array}$ & $\begin{array}{c}-0.041 \\
(0.040)\end{array}$ \\
\hline Overestimate of PA of share partner keeps in $A$ & 282 & 0.181 & 0.240 & $\begin{array}{c}0.025 \\
(0.036)\end{array}$ & $\begin{array}{c}0.032 \\
(0.047)\end{array}$ \\
\hline Overestimate of PA of share partner keeps in B & 281 & 0.205 & 0.224 & $\begin{array}{c}0.006 \\
(0.032)\end{array}$ & $\begin{array}{c}0.007 \\
(0.041)\end{array}$ \\
\hline Overestimate of PA of share partner keeps in C & 282 & 0.201 & 0.204 & $\begin{array}{l}-0.006 \\
(0.041)\end{array}$ & $\begin{array}{l}-0.008 \\
(0.053)\end{array}$ \\
\hline
\end{tabular}

Notes:

Robust standard errors in parentheses: $*, * *, * * *$ indicate significance at the 10,5 , and 1 percent levels respectively. Each row represents migration impact for a single regression or IV regression.

Regressions weighted for population proportions of compliers and non-compliers, and include controls for age, gender, island of birth, ballot years, game order, and partner characteristics.

Game A has full information and the principal applicant (PA) as the claimant on the bonus pot; Game B has full information and the partner as the claimant on the bonus pot; Game $C$ has the principal applicant as the claimant on the bonus pot, but partial information, with the partner only observing how much the PA transfers, not how much they start with. 